African Crop Science Journal by African Crop Science Society is licensed under a Creative Commons Attribution 3.0 Uganda License. Based on a work at www.ajol.info/ and www.bioline.org.br/cs DOI: $\underline{\text { https://dx.doi.org/10.4314/acsj.v29i4.1 }}$

\title{
ARBUSCULAR MYCORRHIZAL FUNGI ASSOCIATED WITH THE RHIZOSPHERE OF Piliostigma reticulatum AND Guiera senegalensis SHRUBS IN SENEGAL
}

\author{
A.F.FALL ${ }^{1,2,3}$, H. FOUNOUNE-MBOUP ${ }^{2}$, S. DIATTA ${ }^{1}$, S. DIAKHATE ${ }^{4}$ and I. NDOYE ${ }^{2}$ \\ 'Laboratoire National de Recherches sur les Productions Végétales, P. O. Box 3120, Dakar, Senegal \\ ${ }^{2}$ Department of Plant Biology, Cheikh Anta Diop University of Dakar, P. O. Box 5005, \\ Dakar, Senegal \\ ${ }^{3}$ African Center of Excellence in Agroecology and Livelihood Systems, Uganda Martyrs University, \\ P. O. Box 5492, Kampala, Uganda \\ ${ }^{4}$ IRD, LMI IESOL, Centre IRD-ISRA, P. O. Box 3120, Dakar, Senegal \\ Corresponding author: abdallahfall@outlook.fr
}

(Received 20 May 2021; accepted 15 August 2021)

\begin{abstract}
Piliostima reticulatum and Guiera senegalensis shrubs constitute "islands of soil fertility" in the rhizosphere, with better availability of water and more intense biological activity in the SudanoSahelian agro-ecosystems. There is, however, paucity of information on diversity of arbuscular mycorrhizal fungi (AMF) fungi, which have a wide ecological range of associations with a variety of vegetation. The purpose of this study was to identify the types of AMF in the rhizospheres of $P$. reticulatum and G. senegalensis shrubs in Senegal. Soil samples were collected from around the shrubs in Keur Matar Arame and Keur Ndary Ndiaye in 2019 after a rainy season. Arbuscular mycorrhizae fungi spores were isolated by the wet sieving method and identified based on their morphological characteristics (shape, size, colour, attached hyphae, and spore ornamentation). Four types of AMF were identified, namely Glomus aggregatum, Sclerocystis rubiformis, Gigaspora margarita and Scutellospora gregaria. In addition, the density of spores was more abundant in the soil outside the shrub canopy compare to the soil beneath the shrub.
\end{abstract}

Key Words: Gigaspora margarita, Glomus aggregatum, Sclerocystis rubiformis

\section{RÉSUMÉ}

Les arbustes Piliostima reticulatum et Guiera senegalensis constituent des «îlots de fertilité » dans la rhizosphere des sols, avec une meilleure disponibilité en eau et une activité biologique plus intense dans les agro-écosystèmes soudano-sahéliens. Cependant, Il y a peu d'informations sur la diversité des champignons mycorhiziens arbusculaires (CMA) qui peuvent s'associer avec une large variété de plantes. Le but de cette étude est d'identifier les types de CMA dans les rhizosphères des arbustes $P$. reticulatum et G. senegalensis au Sénégal. Des échantillons de sol ont été collectés autour des 
arbustes à Keur Matar Arame et Keur Ndary Ndiaye en 2019 après la saison des pluies. Les spores de champignons mycorhiziens arbusculaires ont été isolées par la méthode de tamisage humide et identifiées en fonction de leurs caractéristiques morphologiques (forme, taille, couleur, hyphes attachés et ornementation des spores). Quatre types de CMA ont été identifiés, à savoir Glomus aggregatum, Sclerocystis rubiformis, Gigaspora margarita et Scutellospora gregaria. De plus, la densité des spores était plus abondante dans les sols hors couvert que dans les sols sous-couvert des arbustes.

Mots Clés: Gigaspora margarita, Glomus aggregatum, Sclerocystis rubiformis

\section{INTRODUCTION}

The Sudano-Sahelian region of West Africa, like many other arid and semi-arid environments, is characterised by perennial woody shrubs (Diakhaté et al., 2016). Among these shrubs, Piliostigma reticulatum (DC) Hochst and Guiera senegalensis JF Gmel, are the most common native shrubs found in farmers' fields, where they are traditionally cut and burned as a means of field clearance (Lufafa et al., 2008). Piliostigma reticulatum and $G$. senegalensis improves soil quality and promotes crop growth (Bright et al., 2017). They are known as "islands of fertility, "also termed "resource islands" under and near the vegetation tufts (Wezel et al., 2000). These "resource islands" created by the shrubs are high in water availability and soil nutrients such as nitrogen, phosphorus and potassium (Wezel et al., 2000; Hernandez et al., 2015). It also creates a favourable environment for microbial population and diversity, hence resulting to high decomposition of organic materials (Diedhiou et al., 2009; Dossa et al., 2010).

According to Kizito et al. (2006) and Diakhaté et al. (2013), Piliostigma reticulatum and $G$. senegalensis surrounding microenvironments showed a high level of water availability and diversity of nematode compared to soil outside their influence. They also promote carbon sequestration in intercropping systems (Bright et al., 2017) and influence the diversity of arbuscular mycorrhizal fungi (AMF) in the soil (MaurerTroxler et al., 2006; Bender et al., 2016).

AMF play a key role in plant hydro-mineral nutrition and health. Indeed, several studies have shown the beneficial effects of the AMF on the agro-ecosystems such as improving crop growth, improving soil structure and increasing plant resistance against biotic and abiotic stresses (Gonzalez-Chavez et al., 2009). However, to date, there has not been systematic studies to ascertain the influence of $P$. reticulatum and $G$. senegalensis shrubs on the diversity of AMF. The objective of this study was to characterise the diversity of AMF in the rhizosphere of $P$. reticulatum and $G$. senegalensis shrubs on the abundance of AMF spores.

\section{MATERIALS AND METHODS}

Study area. This study was conducted during November to December of 2019 in the peanut Basin in Senegal. The region is semi-arid with a north Sudanian to sahelian climate (Dacosta, 1989). Mean annual precipitation ranges from 540 to $750 \mathrm{~mm}$, distributed from July to October. The mean annual minimum and maximum air temperatures range from $20^{\circ} \mathrm{C}$ from December to January and $34{ }^{\circ} \mathrm{C}$ from April to June (Diedhiou et al., 2009). Basin soils are sandy, classifying as Calcids and mixed Haplic Ferric Lixisol (FAO, 2006), locally named Dior and Deck-Dior (Badiane et al., 2000). The vegetation of the basin is shrubland with scattered trees (Diouf and Lambin, 2001).

Within the study area, the G. senegalensis site was to the west of the study area (in Keur Matar Arame, $14^{\circ} 46^{\prime} \mathrm{N}, 16^{\circ} 51^{\prime} \mathrm{W}$, in the Diourbel region); whereas the $P$. reticulatum sites were in the Southeast (in Keur Ndary Ndiaye, $13^{\circ} 45^{\prime} \mathrm{N}, 15^{\circ} 47^{\prime} \mathrm{W}$, in the Kaolack 
region). For at least 50 years, the area was in crop rotation between peanuts and millet under local farmer management. Guiera senegalensis and $P$. reticulatum existed at Keur Matar, and Keur Ndary Ndiaye at densities of 1833 and 1300 shrubs ha"1, respectively (Dossa et al., 2012).

Sample selection. The shrub plots were divided into near or shrub cover (SC) and far or out-cover (HC) to investigate AMF diversities beneath the shrub canopy, which includes both the shrub rhizospheric zone versus soils outside the shrub canopy with no direct influence from the shrub canopy (Diedhiou et al., 2013). Soil samples were taken from the rhizospheres beneath the canopies $(0-25 \mathrm{~cm})$ of both shrubs plants. Cores were collect from 15 points and the samples were pooled to obtain representative bulk samples.

The soil was passed through a 2-mm sieve to eliminate large particles, homogenised, placed in closed plastic bags, and stored in the room temperature prior to the experiment. Soils analysis and spores characterisation were carried out in the LCM lab (Laboratoire Commun de Microbiolgie/ IRD/ISRA/UCAD) in the research center of ISRA in Bel Air (Dakar / Senegal).

Isolation and identification of AMF. AMF spores were isolated by wet-sieving and sucrose centrifugation (Gerdemann and Nicolson, 1963). Briefly, $100 \mathrm{~g}$ of soil from each plant rhizosphere were suspended in $1000 \mathrm{ml}$ water, stirred with a spatula stirrer for 1 minute and the solutions were passed through a sequences of sieves $(400,200,50$, and $32 \mu \mathrm{m})$. The soil fraction in the last sieve was collected in a beaker. Twenty-five milliliter of spore suspensions were transferred into 50 $\mathrm{ml}$ centrifugations tubes and centrifuged with $25 \mathrm{ml}$ of $60 \%$ sucrose solution for 2 minutes at $1000 \mathrm{rpm}$. The supernatant was decanted into a 32 ìm sieve, washed, and transferred to Petri dishes. Quantification of spores was carried out in petri dishes under a stereoscopic microscope with 400 times magnification ( $\mathrm{B}^{3}$ aszkowski, 2012). The spore density was expressed as the total number of spores per $100 \mathrm{~g}$ of air-dried soil (McKenney and Lindsey, 1987).

Identification of AMF spores was carried out by observing morphological characters such as shape, size, colour, attached hyphae, and spore ornamentation. For spore identification, the database of AMF specimens by INVAM (2018) (West Virginia University, Morgantown, USA) was used and described as provided by Morton and Benny (1990).

The diversity index was calculated according to Shannon-Weaver for each soil (SC and $\mathrm{HC}$ ), using the formula:

$H=-\sum\left(\frac{n i}{N}\right) \ln \left(\frac{n i}{N}\right)$

Where:

$n i$ represents the density of the spores of the species $i$ and $\mathrm{N}$ the total density of the spores of all the species in a sample.

A low $\mathrm{H}$ value generally suggests a site with few species and a few dominant species, while a high $\mathrm{H}$ value suggests considerably more species.

Statistical analysis. The data collected were analysed using a one-way ANOVA. Fisher's test (LSD) was used to compare the means $(\mathrm{P}<0.05)$. Linear regression was used to clarify the influence of soil chemical parameters on communities of AMF fungi. Statistical analyses were performed using XLSTAT software (Version 2013.1).

Principal Components Analysis (PCA) was performed using Minitab 17 software, to determine relationship between soil chemical properties $(\mathrm{C}, \mathrm{N}$ and $\mathrm{P})$ and spores abundance. Scores of samples in Axis 1 and Axis 2 were further analysed using permutational multivariate analysis of variance 
(PerMANOVA) (Anderson, 2001) to determine the statistical significance of any treatment.

\section{RESULTS}

Abundance and diversity of AMF spores. The abundance of AMF spores was significantly higher $(\mathrm{P}<0.05)$ in soil without the shrubs (P. reticulatum and G. senegalensis) than the soils from the rhizosphere of the shrubs (Table 1). Spore density also displayed a similar parttern, with spores being more diversified in the control soil (without the shrubs) than in the rhizospheric soil of the shrubs (Table 1).

Three morpho-species were found in the rhizosphere of the shrubs (P. reticulatum and G. senegalensis) and one more in the control (without the shrubs) (Table 1). These species belonged to three genera; with two species belonging to the Glomeraceae family (Glomus aggregatuma nd Sclerocy stisrubiformis), and two to Gigasporaceae family (Gigaspora margarita and Scutello sporagregaria) (Fig. 1). Sclerocystis rubiformis was found exclusively in the control (without the presence of the shrubs).

With regard to the density, Glomus aggregatum and Gigaspora margarita had a relatively higher density of spores compared to Sclerocystis rubiformis and Scutellospora gregaria (Table 1). A comparison of the soils showed that the Diversity Index was higher in the soil outside the shrubs canopies $(\mathrm{H}=1.00)$ than in the soil beneath the shrubs canopies $(\mathrm{H}=0.71)($ Table 1$)$.

For $P$. reticulatum, the comparison of the means also showed that the number of spores of AMF was significantly higher in the control $(300 \pm 84$ per $100 \mathrm{~g}$ of dry soil) than in the presence of the shrubs $(201 \pm 42$ per $100 \mathrm{~g}$ of dry soil) $\mathrm{P}<0.01$. A similar trend was observed for $G$. senegalensis.

Soil chemical properties and abundance of AMF. It was clear that the abundance of AMF spores was negatively correlated with the quantity of soil organic $\mathrm{C}(\mathrm{r}=-0.28, \mathrm{P}<0.001)$,

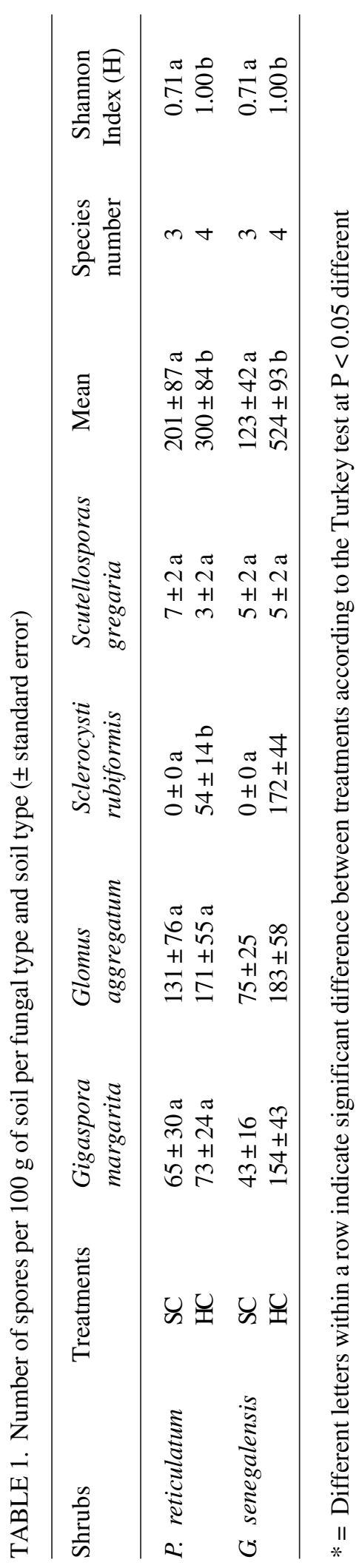


organic $\mathrm{N}(\mathrm{r}=-0.47, \mathrm{P}<0.001)$ and available $\mathrm{P}(\mathrm{r}=-0.67, \mathrm{P}<0.01)$. The three elements $(\mathrm{C}$, $\mathrm{P}$ and $\mathrm{N}$ ) had a negative influence on the abundance of AMF spore (Table 2).
Multivariate analysis of all data showed a strong clustering by soil location $(\mathrm{P}<0.01)$ (Fig. 2). Principal component analysis of the abundance of the spore of AMF showed a

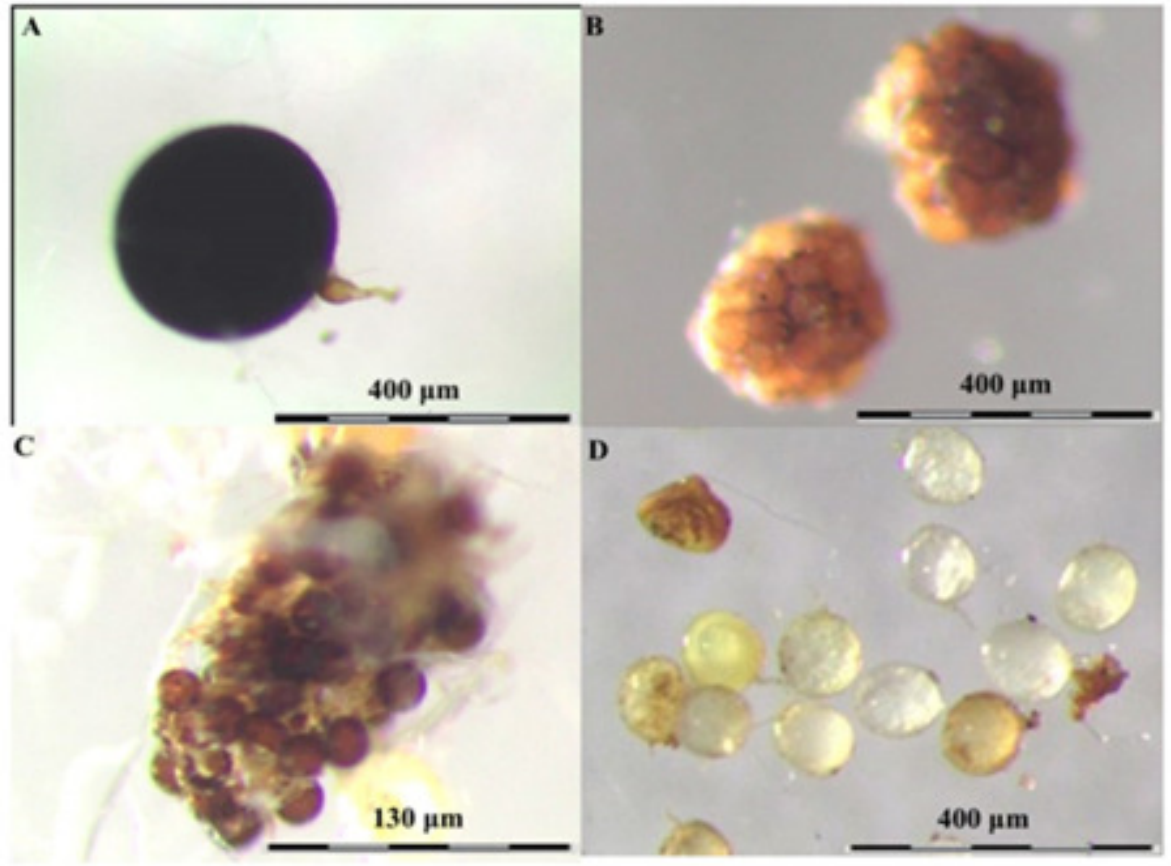

Figure 1. Spore diversity in soil within and outside the influence of $P$. reticulatum shrub. A: Spore of Scutellospora gregaria is found in all soils. Its spores are large and visible to naked eye, black and have a suspending bulb. B: Sclerocystis rubiformis is the species characteristic of soil outside the influence of P. reticulatum. The spores are inseparable cluster and brown. C: Spore of Glomus aggreagatum, is present in all soils. It forms spores in brown clusters. D: Spore of Gigaspora margarita is found in all soils. The spores are medium-sized, whitish and yellowish with a suspending bulb.

TABLE 2. Chemical properties of the rhizospheric soils beneath the shrubs and the soil without the shrubs in Senegal ( \pm standard error)

\begin{tabular}{|c|c|c|c|c|}
\hline \multirow[t]{2}{*}{ Soil parameters } & \multicolumn{2}{|c|}{ P. reticulatum } & \multicolumn{2}{|c|}{ G. senegalensis } \\
\hline & Control (HC) & $\begin{array}{l}\text { Rhizospheric } \\
\text { soil (SC) }\end{array}$ & Control (HC) & $\begin{array}{l}\text { Rhizospheric } \\
\text { soil (SC) }\end{array}$ \\
\hline Total C $\left(\mathrm{mg} \mathrm{C} \mathrm{g}^{-1}\right)$ & $2.50 \pm 0.77 \mathrm{a}^{*}$ & $4.00 \pm 0.40 b$ & $1.50 \pm 0.14 \mathrm{a}^{*}$ & $3.44 \pm 0.48 \mathrm{a}^{*}$ \\
\hline Total N $\left(\mathrm{mg} \mathrm{N} \mathrm{g}^{-1}\right)$ & $0.22 \pm 0.01 \mathrm{a}$ & $0.36 \pm 0.01 b$ & $0.20 \pm 0.01 \mathrm{a}$ & $0.40 \pm 0.02 b$ \\
\hline Total $\mathrm{P}\left(\mu \mathrm{g} \mathrm{P} \mathrm{g}^{-1}\right)$ & $42.30 \pm 3.23 \mathrm{a}$ & $59.50 \pm 5.77 b$ & $13.30 \pm 0.33 a$ & $95.0 \pm 7.32 b$ \\
\hline $\mathrm{pH}\left(\mathrm{H}_{2} \mathrm{O}\right)$ & $5.5 \pm 0.1 \mathrm{a}$ & $5.5 \pm 0.1 \mathrm{a}$ & $5.4 \pm 0.1 \mathrm{a}$ & $5.2 \pm 0.1 \mathrm{a}$ \\
\hline
\end{tabular}

*= Means followed by different letter within a row indicate significant difference between treatments (HC/SC) at $\mathrm{P}<0.05$ 


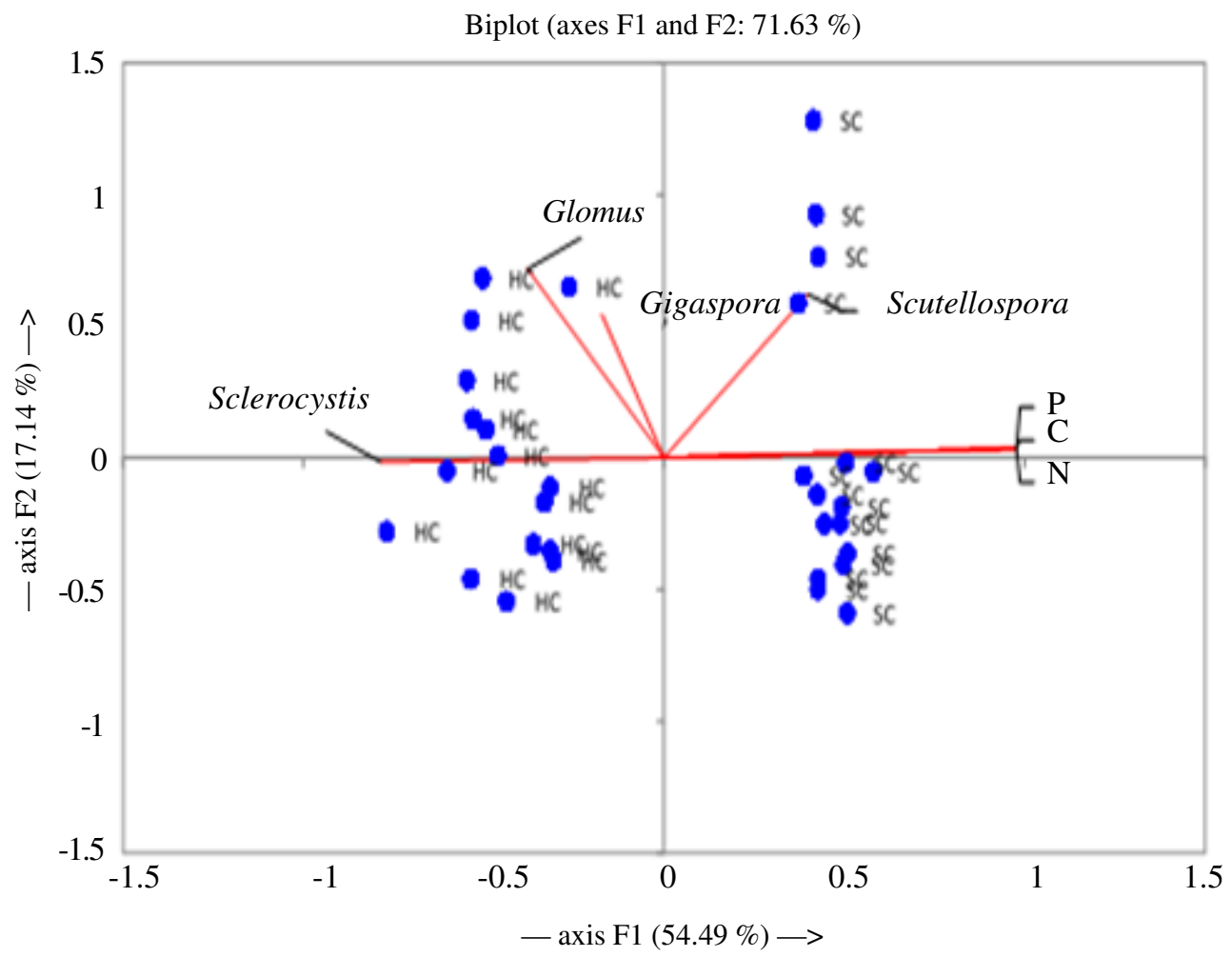

Figure 2. Principle component analysis of the abundance of AMF spore from soil beneath and outside the shrubs canopy influence. $\mathrm{HC}=$ outside beneath of canopy, $\mathrm{SC}=$ beneath canopy $\mathrm{C}=$ carbon; $\mathrm{P}=$ phosphorus and $\mathrm{N}=$ nitrogen.

distinct separation of clusters along the first axis $(54.5 \%$ of the total variance) based on the soil chemical properties. The second axis accounted for only $17.1 \%$ of the variability. Samples were clustered separately between data from beneath and outside the canopy influence. Total N, P and C were negatively correlated with the abundance of spores of Glomus, Sclerocystis and Gigaspora $(\mathrm{P}<0.01)$.

\section{DISCUSSION}

Diversity and abundance of AMF spores. The density of AMF spores in the rhizosphere of the shrubs ( $P$. reticulatum and $G$. senegalensis) was relatively low (on average 201 and 109 spores per $100 \mathrm{~g}$ of dry soil for $P$. reticulatum and $G$. senegalensis, respectively), compared to the AMF spores from the control (on average 300 and 144 spores per $100 \mathrm{~g}$ of dry soil for $P$. reticulatum and G. senegalensis, respectively). These results are in accordance with those obtained by Dabiré et al. (2007), who showed that the absence of vegetation (bare soil) is hardly conducive to the development of fungi; hence the presence of a high quantity of spores which is the form of resistance of fungi to unfavourable environmental conditions. Indeed, AMF being obligatory symbionts, need host plants to maintain themselves in the soil.

The rhizhospheric soil had fewer spores than the control soil (Table 1) perhaps because of the presence of the shrubs, which accelerated spore germination to rapidly infect new roots and the mycorrhizae sporulate continuously (Hamid and Renard, 2003). Overall, the density of spores in rhizhosphere of the shrubs was lower than that found in plantations of Acacia holosericea and Acacia 
mangium in the southern and northern regions of Sudan in Burkina Faso (Bâ et al., 1996); and that of Acacia albida in different regions from Senegal (Diop et al., 1994). The density of Glomeromycota spores was generally higher in the control in the present study than in rhizhosphere of the shrubs (Table 1).

Using morphological identification, four morphotypes were found in all soils (Table 1), yet Diallo et al. (1999) found nine morphotypes in the semi-arid regions of Senegal. Morphological identification does not allow assessment of the real diversity in terms of fungal species. However, the morphotypes were related to the genera Glomus, Gigaspora, sclerocistys and Scutellospora. The morphotypes of Glomeraceae family were dominant in both soils (rhizosphere and nonrhizosphere) and spores of the genus Glomus were more abundant.

The predominance of Glomeracea has also been reported in some studies based on AMF morphotypes in various tropical soils (Bâ et al., 1996; Diallo et al., 1999; Houngnandan et $a l ., 2009)$ and in certain agricultural soils of temperate zones (Mathimaran et al., 2005). Indeed, in the semi-arid zones in Senegal, Glomus is numerically more important than others genus (Diop, 1995; Diallo et al., 1999). According to Bourou (2012), in arid areas of Africa, the best-known AMF belongs to the genus Glomus and Gigaspora. Indeed, the genus Glomus is considered to be the most associated with woody plants in dry areas of Africa (Bouamri et al., 2006). Hatimi and Tahrouch (2007) reported that Glomus was the most ubiquitous AMF.

Our results have revealed that at morphological level of the spores, there are dismal differences in the composition of AMF from rhizhosphere of the shrubs and in the soil control. The same morphotypes are found on both treatment conditions, but only in different quantities. The absence of the shrubs significantly $(\mathrm{P}=<0.05)$ favoured the abundance of spores of AMF (Table 1). The results confirm the assertion by Bogie et al.
(2018) that the beneficial effects of the shrubs through hydraulic redistribution for the benefit of the crops may not favor the presence of AMF spores.

Sclerocystis rubiformis is a characteristic species of the control. This species is not found in the rhizosphere of the shrubs. Glomus aggregatum has been reported from the rhizosphere of palm-oil in Java (Widiastuti and Kramadibrata, 1992) and Chrysophyllum cainito (Destifani, 2013). Sclerocystis rubiformis has been reported in Cordoba from the rhizosphere of poacea (Lugo and Cabello, 2002). In Mexico, S. rubiformis has been reported from the rhizosphere of cocos nucifera in a coconut-growing area along the coastline and the inland in the tropical forest of Yucatan (Lara-Perez et al., 2020). Gigaspora margarita on the other hand, has been identified from the rhizosphere of Vigna unguiculata in Senegal (Diop et al., 2021). Scutetellospora gregaria has been also reported from the rhizosphere of Borreria articularis in west coast of India (Beena et al., 2001).

\section{Soil chemical properties and diversity of}

AMF. This study has revealed that richness and abundance in fungal are negatively influenced by the richness of $\mathrm{P}, \mathrm{C}$ and nitrogen in the rhizosphere soil (Fig. 2). When the concentration of $\mathrm{N}, \mathrm{P}$, and $\mathrm{C}$ in the soil is low, the richness of AMF increases.

The results of the PCA (Fig. 2) confirm those of the Pearson correlation with regard to the abundance of spores in relation to the soil chemical properties. In addition, we found that the variation in AMF community structure according to soil type was mainly explained by $\mathrm{N}, \mathrm{P}$ and $\mathrm{C}$ levels. These results are consistent with those of Cuenca and Meneses (1996) and Isobe et al. (2007), who indicated that the abundance and diversity of AMF communities associated with cocoa, were negatively correlated with the available $\mathrm{P}$ in the soils. According to Johnson et al. (2013), certain morpho-species are more sensitive to available $\mathrm{P}$ and become less frequent and 
undetectable in soils with high level of available P. The low species richness in both soils (with and without shrubs) could be due to limited or non-existent sporulation in the soils of certain species since many AMF species can end their life cycle with sporulation only towards the end of the wet season, to survive during the dry season. Another reason is, the previous crop grown in the sites was pearl millet, which has a low mycorrhizal dependency (Rao et al., 1985)

\section{CONCLUSION}

This study has shown that $P$. reticulatum and G. Senegalensis shrubs are naturally associated with a range of AM fungi in the soils of the Sudano-Sahelian agro-ecosystems of Senegal. Four species (Glomus aggregatum, Sclerocystis rubiformis, Gigaspora margarita and Scutellospora gregaria) were identified in the rhizosphere of the shrubs from two sites. Glomus is the most represented genus; followed by Gigaspora in the different soils. Our results also revealed that AMF communities were clustered according to soil chemical properties (N, P and C). Future research should focus on the use of soil these AMF species in order to develop highly effective and competitive inoculants for pearl millet and groundnut cultivation in these different and sites.

\section{ACKNOWLEDGEMENT}

This study was funded by the USAID PEER Programme under grant agreement: \#AIDOAA-A-11-00012 in collaboration with the US National Science Foundation.

\section{REFERENCES}

Anderson, M.J. 2001. A new method for non parametric multivariate analysis of variance. Austral Ecology 26(1):32-46. https://doi.org/10.1111/j.1442-9993.2001. 01070.pp.x
Bâ, A.M., Dalpé, Y. and Guissou, T. 1996. Les Glomales d'Acacia holosericea et d'Acacia mangium. Bois \& Forets des Tropiques 250:5-18.

Badiane, A. N., Khouma, M. and Sene M. 2000. Region de Diourbel: Gestion des sols. Drylands Research Working Paper 15. Drylands Research, Somerset, England, p. 25. https://doi.org/10.19182/bft1996. 250.a19862

Beena, K.R., Arun, A.B., Raviraja, N.S. and Sridhar, K.R. 2001. Association of arbuscular mycorrhizal fungi with plants of coastal sand dunes of west coast of India. Tropical Ecology 42(2):213-222.

Bender, S.F., Wagg, C. and van der Heijden, M.G. 2016. An underground revolution: biodiversity and soil ecological engineering for agricultural sustainability. Trends in Ecology \& Rvolution 31(6):440-452. https://doi.org/10.1016/j.tree.2016.02.016

Blaszkowski, J. 2012. Glomeromycota. W. Szafer Institute of Botany, Polish Academy of Sciences.

Bogie, N.A., Bayala, R., Diedhiou, I., Conklin, M.H., Fogel, M.L., Dick, R.P. and Ghezzehei, T.A. 2018. Hydraulic redistribution by native sahelian shrubs: bioirrigation to resist in-season drought. Frontiers in Environmental Science 6:98 https://doi.org/10.3389/ fenvs.2018.00098

Bouamri, R., Dalpé, Y., Serrhini, M.N. and Bennani, A. 2006. Arbuscular mycorrhizal fungi species associated with rhizosphere of Phoenix dactylifera L. in Morocco. African Journal of Biotechnology 5(6):10516.

Bourou, S. 2012. Étude éco-physiologique du tamarinier (Tamarindus indica L.) en milieu tropical aride. Doctoral dissertation, Ghent University, Belgium. 193pp.

Bright, M.B., Diedhiou, I., Bayala, R., Assigbetse, K., Chapuis-Lardy, L., Ndour, Y. and Dick, R.P. 2017. Long-term Piliostigma reticulatum intercropping in the Sahel: Crop productivity, carbon 
sequestration, nutrient cycling, and soil quality. Agriculture, Ecosystems \& Environment 24(2):9-22.

Cuenca, G. and Meneses, E. 1996. Diversity patterns of arbuscular mycorrhizal fungi associated with cacao in Venezuela. Plant and Soil1 83(2):315-322. https://doi.org/ 10.1007/BF00011447

Dabiré, A.P., Hien, V., Kisa, M., Bilgo, A., Sangare, K.S., Plenchette, C., Galiana, A., Prin, Y. and Duponnois, R. 2007. Responses of soil microbial catabolic diversity to arbuscular mycorrhizal inoculation and soil disinfection. Mycorrhiza 17(6):537-545.

Dacosta, H. 1989. Précipitations et écoulements sur le bassin de la Casamance. Dakar: ORSTOM, multigr. Doctoral dissertation, Thèse 3e cycle, Université Cheikh Anta Diop de Dakar, Sénégal.

Destifani, Y.F. 2013. Arbuscular mycorrhizal fungi on star apple (Chrysophyllum cainito) at IPB Darmaga Campus. Undergraduate Thesis, Bogor Agricultural University, Indonesia.

Diakhaté, S., Gueye, M., Chevallier, T., Diallo, N.H., Assigbetsé, K., Abadie, J., Diouf, M., Masse, D., Sembène, M., Ndour, Y.B. and Dick, R.P. 2016. Soil microbial functional capacity and diversity in a millet-shrub intercropping system of semi-arid Senegal. Journal of Arid Environments 12(9):71-79. https://doi.org/10.1016/ j.jaridenv.2016.01.010

Diakhaté, S., Villenave, C., Diallo, N.H., Ba, A.O., Djigal, D., Masse, D., Sembène, P.M. and Chapuis-Lardy, L. 2013. The influence of a shrub-based intercropping system on the soil nematofauna when growing millet in Senegal. European Journal of Soil Biology 5(7):35-41. https://doi.org/10. 1016/j.ejsobi.2013.04.003

Diallo, A.T., Samb, P.I. and Ducousso, M. 1999. Arbuscular mycorrhizal fungi in the semi-arid areas of Senegal. European Journal of Soil Biology 35(2):65-75.
https://doi.org/10.1016/S 1164 5563(99)00110-7

Diedhiou, S., Dossa, E.L., Badiane, A.N. Diedhiou, I., Sene, M. and Dick, R.P. 2009. Decomposition and spatial microbial heterogeneity associated with native shrubs in soils of agroecosystems in semi-arid Senegal. Pedobiologia 52(4):273-286. https://doi.org/10.1016/j.pedobi.2008. 11.002

Diedhiou-Sall, S., Dossa, E.L., Diedhiou, I., Badiane, A.N., Assigbetsé, K.B., Ndiaye Samba, S.A., Khouma, M., Sène, M. and Dick, R.P. 2013. Microbiology and macrofaunal activity in soil beneath shrub canopies during residue decomposition in agroecosystems of the Sahel. Soil Science Society of America Journal 77(2):501-511. https://doi.org/10.2136/sssaj2012.0284

Diop, T.A., Gueye, M., Dreyfus, B.L., Plenchette, C. and Strullu, D.G. 1994. Indigenous arbuscular mycorrhizal fungi associated with Acacia albida Del. in different areas of Senegal. Applied and Environmental Microbiology 60(9):34333436.

Diop, T. 1995. Ecophysiologie des champignons mycorhiziens à vésicules et arbuscules associés à Acacia albida dans les zones Sahéliennes et SoudanoGuinéenne du Sénégal (Doctoral dissertation).

Diop, I., Ndoye, F., Diédhiou, A. and KrasovaWade, T. 2021. Diversity and spore density of arbuscular mycorrhizal fungi in the rhizosphere of cowpea (Vigna unguiculata [L.] Walp.) cultivated in different soils in Senegal.

Diouf, A. and Lambin, E.F. 2001. Monitoring land-cover changes in semi-arid regions: remote sensing data and field observations in the Ferlo, Senegal. Journal of Arid Environments 48(2):129-148.

Dossa, E.L., Diedhiou, I., Khouma, M., Sene, M., Lufafa, A., Kizito, F., Samba, S.A.N., Badiane, A.N., Diedhiou, S. and Dick, R.P. 
2012. Crop productivity and nutrient dynamics in a shrub (Guiera senegalensis)based farming system of the Sahel. Agronomy Journal 104(5):12551264. https://doi.org/10.2134/agronj2011. 0399

Dossa, E.L., Diedhiou, S., Compton, J.E., Assigbetse, K.B. and Dick, R.P. 2010. Spatial patterns of $P$ fractions and chemical properties in soils of two native shrub communities in Senegal. Plant and Soil 327(1):185-198. https://doi.org/ 10.1007/s11104-009-0044-8

FAO, I. 2006. ISRIC: World Reference Base for soil resource in World Soil Resource Report no. 103. FAO, Rome, Italy.

Gerdemann, J.W. and Nicolson, T.H. 1963. Spores of mycorrhizal endogone species extracted from soil by wet sieving and decanting. Transactions of the British Mycological Society 46(2):235-244.

Gonzalez-Chavez, M.C., Carrillo-Gonzalez, R. and Gutierrez-Castorena, M.C. 2009. Natural attenuation in a slag heap contaminated with cadmium: The role of plants and arbuscular mycorrhizal fungi. Journal of Hazardous Materials 161(2-3):1288-1298. https://doi.org/ 10.1016/j.jhazmat.2008.04.110

Hamid, A. and Renard, A. 2003. Statuts des mycorhizes à arbuscules. Etude de la mycorhization de quelques espèces végétales présentant un intérêt pour la restauration écologique, Université de la Nouvelle Calédonie, Rapport n ${ }^{\circ}$ 5. 36pp.

Hatimi, A. and Tahrouch, S. 2007. Caractérisations chimique, botanique et microbiologique du sol des dunes littorales du Souss-Massa. Biomatec Echo 2(5):8597.

Hernandez, R.R., Debenport, S.J., Leewis, M.C.C., Ndoye, F., Soumare, A., Thuita, M., Gueye, M., Miambi, E., Chapuis-Lardy, L., Diedhiou, I. and Dick, R.P. 2015. The native shrub, Piliostigma reticulatum, as an ecological "resource island" for mango trees in the Sahel. Agriculture, Ecosystems
\& Environment 20(4):51-61. https:// doi.org/10.1016/j.agee.2015.02.009

Houngnandan, P., Yemadje, R.G.H., Kane, A., Boeckx, P. and Van Cleemput, O. 2009. Les glomales indigènes de la forêt claire à Isoberlinia doka (Craib et Stapf) à WariMaro au centre du Bénin. Tropicultura 27(2):83-87.

INVAM, 2018. International Culture Collection of (Vesicular) Arbuscular Mycorrhizal Fungi. West Virginia University. https://invam.wvu.edu/

Isobe, K., Aizawa, E., Iguchi, Y. and Ishii, R. 2007. Distribution of arbuscular mycorrhizal fungi in upland field soil of Japan 1. Relationship between spore density and the soil environmental factor. Plant Production Science 10(1):122-128. https:/ /doi.org/10.1626/pps.10.122

Johnson, J.M., Houngnandan, P., Kane, A., Sanon, K.B. and Neyra, M. 2013. Diversity patterns of indigenous arbuscular mycorrhizal fungi associated with rhizosphere of cowpea (Vigna unguiculata (L.) Walp.) in Benin, West Africa. Pedobiologia 56(3):121-128. https:// doi.org/10.1016/j.pedobi.2013.03.003

Kizito, F., Dragila, M., Sene, M., Lufafa, A., Diedhiou, I., Dick, R.P., Selker, J.S., Dossa, E., Khouma, M., Badiane, A. and Ndiaye, S. 2006. Seasonal soil water variation and root patterns between two semi-arid shrubs co-existing with Pearl millet in Senegal, West Africa. Journal of Arid Environments 67(3):436-455. https:/ /doi.org/10.1016/j.jaridenv.2006.02.021

Lara-Pérez, L.A., Oros-Ortega, I., CórdovaLara, I., Estrada-Medina, H., O'ConnorSánchez, A., Góngora-Castillo, E. and Sáenz-Carbonell, L. 2020. Seasonal shifts of arbuscular mycorrhizal fungi in Cocos nucifera roots in Yucatan, Mexico. Mycorrhiza 30(2):269-283.

Lufafa, A., Diédhiou, I., Samba, S.A.N., Séné, M., Khouma, M., Kizito, F., Dick, R.P., Dossa, E. and Noller, J.S. 2008. Carbon stocks and patterns in native shrub 
communities of Senegal's Peanut Basin. Geoderma 146(1-2):75-82. https:// doi.org/10.1016/j.geoderma.2008.05.024

Lugo, M.A. and Cabello, M.N. 2002. Native arbuscular mycorrhizal fungi (AMF) from mountain grassland (Córdoba, Argentina) I. Seasonal variation of fungal spore diversity. Mycologia 94(4):579-586.

Mathimaran, N., Ruh, R., Vullioud, P., Frossard, E. and Jansa, J. 2005. Glomus intraradices dominates arbuscular mycorrhizal communities in a heavy textured agricultural soil. Mycorrhiza 16(1):61-66.https://doi.org/10.1007/ s00572-005-0014-9

Maurer-Troxler, C., Chervet, A., Ramseier, L., Sturny, W.G. and Oberholzer, H.R. 2006. Soil biology after ten years of no-and conventional tillage. Revue Suisse d'Agriculture 38:89-94.

McKenney, M.C. and Lindsey, D.L. 1987. Improved method for quantifying endomycorrhizal fungi spores from soil. Mycologia 79(5):779-782. https:// doi.org/10.1080/00275514.1987.12025458
Morton, J.B. and Benny, G.L. 1990. Revised classification of arbuscular mycorrhizal fungi (Zygomycetes): A new order, Glomales, two new suborders, Glomineae and Gigasporineae, and two new families, Acaulosporaceae and Gigasporaceae, with an emendation of Glomaceae. Mycotaxon 37:471-491.

Rao, N.S., Tilak, K.V.B.R. and Singh, C.S. 1985. Effect of combined inoculation of Azospirillum brasilense and vesiculararbuscular mycorrhiza on pearl millet (Pennisetum americanum). Plant and Soil 84(2):283-286.

Wezel, A., Rajot, J.L. and Herbrig, C. 2000. Influence of shrubs on soil characteristics and their function in Sahelian agroecosystems in semi-arid Niger. Journal of Arid Environments 44(4):383-398. https:// doi.org/10.1006/jare.1999.0609

Widiastuti, H. and Kramadibrata, K. 1992. Vesicular-arbuscular mycorrhizal fungi on selected acid soil of West Java. Menara Perkebunan 60(1):9-19. 